\title{
The 1999 Belgian Food Crisis. Development and Management
}

\author{
De Brouwer Christophe \\ Laboratoire de Santê au travail et de Toxicologie du Milieu \\ Ecole de Santé Publique \\ Université Libre de Bruxelles \\ B-1070 Brussel 808, Route de Lennik \\ Belgium
}

(Received 15 February 2001; and accepted 28 Februry 2001)

\begin{abstract}
The Belgian PCB' (poly chlorinated bisphenye) and dioxin crisis, but also that of the BSE (bovine spongiform encephalopathy) in the European Union were significant events in the administrative reorganisation of the foodstuff expertise and of the follow-up of the whole of transformation process for the European Community countries and for the European Union. Many countries unified their food chain risk analysis (for example Great Britain, but also the European Union). Others went further. They unified the risk analysis and the risk management of their food chain. This is for instance the case in Belgium. Through an analysis of principal stages of the belgian PCB's and dioxin food crisis, of its importance, the attitude of Belgian authorities and the reactions of European Community, this study tries to release the general outlines which show an irresistible evolution towards a significant degree of centralisation of fragmented administrations in charge of food risk analysis and eventually of food risk management in the European Union.
\end{abstract}

The Belgian dioxin crisis has known a brutal media development.

A press release by the Belgian Ministry of Agriculture in agreement with the Ministry of Public Health was published on May $27^{\text {th }} 1999$. The communique indicated a contamination of animal food by dioxin in Belgium. The European Commission was only informed the next day by the media's. The Commission asked the Belgian government to send a Rapid Alert System (RAS) official report, which was done the same day. On May $31^{\text {th }}$, an internal note of the Institute of Veterinary Expertise dated April $28^{\text {th }}$ was released. The note was signed by a veterinarian of

Correspondance to: Dr De Brouwer Christophe at the above address. Email: de.brouwer.christophe@ulb.ac.be the Institute who was also an insurance expert, and observed that the contamination by dioxin concerned not only animal food but also human food. On the next day, The Minister of Agriculture and the Minister of Health resigned, since they were accused of minimising the importance of dioxin crisis.

This crisis started on January 1999 and was resumed at the end of 1999 by an official parliamentary inquiry. Its impact was mainly economical.

This paper relates the reason why this crisis developed, mainly because of the parcelling of supervision within the food supply chain, because of the reaction of the European Commission based on the precaution principle and because of the measures taken by Belgium compared to other European countries for the improvement of qual- 
ity control for food supplies.

\section{DEVELOPMENT}

\section{Organisation of quality control for food supplies in Belgium before the "dioxin" crisis}

In Belgium, two ministries share the control of food supplies. The Ministry of Agriculture controls the living animals and the Ministry of Health has authority on all phases from slaughtering to supply of food to the consumer.

a) The Ministry of Agriculture includes two general directorates, which control the living animals. The first directorate is competent for animal food supply (A1). The second board includes veterinary inspection and the quality inspection of veterinary products (A2).

b) The Ministry of Health includes an Institute of Veterinary Expertise (H1) and an Inspection of Human Food Supplies (H2).

The development of the Belgian crisis is mainly due to a lack of transmission of information between inspection teams within the same Ministry and to a lack of collaboration between the two Ministries. The crisis was amplified by the conflict of interest of a veterinarian who was both an insurance expert (EXP) and a director of the Institute of Veterinary Expertise of the Ministry of Health. Finally, a nutritionist (NUT) from a private company applied with discernment the quality accreditation owned by his company. This was an important element for the disclosure of the problem.

Belgium is a federal state. The central authority (federal authority) is competent for all the food supply chain. But the decentralised authorities (federated entities) are competent for the wastage. Thus the complex federal organisation of the country has not been a cause of dysfunction in this crisis except for the wastage. In fact, it was an unintentional recycling of contaminated animal fat in the food supply chain: from the moment animals are taken out of the food supply chain, they are considered as wastes and are therefore under the authority of the federated entities instead of the federal authority. The tracking is lost. They are recycled as animal meal and reincorporate in the food supply chain. It should be noted that this type of complex organisation is not a Belgian exclusivity but is generally found in many occidental countries.

\section{The development of the crisis}

The first contamination by PCBs and dioxin was rapidly observed in susceptible animals since they were massively exposed. They acted as "biological sentinels" and without them, the contamination of the food supply chain could have been not discovered.

Despite severe regulations authorising only the use of animal fat in animal food, a fat melter intentionally and chronically used frying fat mixed with animal fat. A specialised company collected the frying fat. It is most probable that PC Bs were secretly introduced in the collection since it presented some visual similarity with frying fat.

The fat melter was then selling his brand to an animal food trade company. In January 1999, the nutritionist (NUT) of this company was alerted by some complaints from poultry farmers and realised several tests (heavy metals etc...) in order to understand some symptoms observed in chicks. These tests were negative. The food producer informed its insurance company. On the basis of a quality system, the GMP (Good Manufacturing Practices) quality accreditation, he decided to destroy a one-day chick production. It should be noted that these chicks fat would be brought back into the food chain.

By the end of January, problems started to appear in laying hen: a decrease in egg laying and in hatching. Mortality increased in chicks born in February.

On March $16^{\text {th }}$, the nutritionist made the assumption of dioxin contamination and two days later, warned the general directorate for Animal Food of the Ministry of Agriculture (A1). On the basis of his quality accreditation, he decided to realise a tracking of the contamination: he asked for the analysis of some samples that he had collected along the way. He actually needed the accreditation to be able to export to The Netherlands. In this context, he appealed to the RIKILT (official Dutch laboratory for the control of foodstuff and one of the only labs in the region for the analysis of dioxins). The accreditation was the second element for understanding why the contamination was discovered. He informed his insurance.

On the $21^{\text {th }}$ of April, RIKILT informed the nutritionist on the phone of the presence of dioxin in the samples and on the $23^{\text {rd }}$, of a high level of dioxin. The general directorate for Ani- 
mal Food (A1) was immediately alerted, as well as the veterinary expert of the insurance company (EXP). The veterinary expert, also director of the Institute of Veterinary Expertise of the Ministry of Health ( $\mathrm{Hl})$ issued a report for his insurance company and a note dated April $27^{\text {th }}$ which he faxed on the next day to the general directorate for Animal Food (A1). But he did not bring the facts to the attention of his own hierarchy of the Ministry of Health. As director of the Institute of Veterinary Expertise, he actually authorised the slaughtering of the chicken on April $21^{\text {th }}$, since he estimated that the contamination and its consequences were over.

The note of the veterinary expert (EXP) dated April $28^{\text {th }}$, as well as the insistence of the animal food producer lead to a common meeting on the same day with the general directorate for Animal Food (A1) and the general directorate of Veterinary Inspection (A2). It was then decided to officially control the results of the analyses realised by RIKILT. The two directorates started to collaborate in order to establish the list of companies concerned.

On May $18^{\text {th }}$, some samples were collected on pigs (there was manifestly a new introduction of the contamination via animal meal from contaminated animals).

The Ministry of Public Health (responsible for human hygiene) was alerted on the telephone on April $27^{\text {th }}$ by the general directorate for Animal Food. The note of the veterinary expert (EXP, member of the administration of the Ministry of Health) also reached the Ministry of Health by the same means. But it is only on May $11^{\text {th }}$ that the two ministries organised a co-ordination meeting. A preliminary list of companies breeding reproductive chicken was established and sent to the Institute of Veterinary Expertise ( $\mathrm{H} 1)$ on May $17^{\text {th }}$. But the facts were brought to the attention of the Inspection of Human Food Supplies $(\mathrm{H} 2)$ through the media only on May $28^{\text {th }}$. It should be noted that the Institute of Veterinary Expertise $(\mathrm{H} 1)$ and the Inspection of Human Food supplies (H2) were debating on their respective competencies since the beginning of May and the Inspection of Human Food Supplies passed on responsibilities to the Institute of Veterinary Expertise (H1).

However, the use of the European alert system RAS (Rapid Alert system) is the only competence of the Inspection of Human Food Supplies (H2). It is only on May $28^{\text {th }}$ that $\mathrm{H} 2$ realises an RAS notification as asked by the European Authorities, themselves alerted by the media.

On May $4^{\text {th }}$, the three first producers of chicken and pigs were blocked on the basis of the tracking realised from the list of the animal food producers, which were clients of the fat melter. Other companies followed soon. On May $26^{\text {th }}$, the results of the official control realised by RIKILT were finally disclosed and all the companies identified by the tracking were therefore blocked. Since Belgium was unable to release a reliable list of companies involved, the European Union prohibited, on the European Union territory, all chicken, beef and pork products from Belgium. By the end of July, the Belgian authorities adopted a systematic method of analysis for PCBs in the food supply, which was accepted by the European Commission. The exportations could resume slowly. The production indexes published by the Ministry of Economic Affairs shows that the major impact on food production is observed during the month of June. The production was back to normal levels in September $(-10 \%$ in June; $-2.5 \%$ in July-August; $-1.5 \%$ in September). The production of the fishing industry increased on a long-term basis from that moment. Paradoxically, the production of animal food also increased temporarily: as a result of slaughtering prohibition, many animals were to be fed for a longer time.

The European Union's decisions were summarised on December $3^{\text {rd }} 1999$ (1999/788/EC; Document 399D0788; Official Journal L 310, 04/12/ 1999 p. 0062-0070). The Commission decision on protective measures with regard to contamination by dioxins of certain products of porcine and poultry origin intended for human or animal consumption, concerns the fact that:

Belgium shall prohibit the placing on the market of these products, from 15 January 1999.

The prohibition set out in previous paragraph shall not apply where:

(a) The results of analysis demonstrate that the products are not contaminated with dioxins or, that they do not exceed the levels for $P C B$ set out (see below), or

(b) The products were derived from animals slaughtered after 20 September 1999 or from eggs laid after that date.

\section{Belgium facing European partners}

The information on food contamination is the 
object of a double regulation in the European Union. On one hand, there is an obligation of veterinary notification in case of a disease, which may be a danger for the livestock or for public health $(90 / 425 / \mathrm{EC}$ and $89 / 662 / \mathrm{EC})$. On the other hand, the RAS notification $(92 / 59 / \mathrm{EC})$ concerns only the marketed food supply. The European Commission asks its Standing Veterany Committee to examine food supply problems in one of the member countries. Finally, bilateral information can circulate between countries and in particular neighbour countries. The Netherlands were informed of the problem by RIKILT on April $29^{\text {th }}$. They were alerted a second time by the general directorate for Animal Food (A1) in order to collaborate to the tracking. Officially, the general directorate of Veterinary Inspection and the Quality Inspection of Animal Products (A2) informed France and The Netherlands on May $19^{\text {th }}$. These countries did not block Belgian exportation at that moment.

At the time of dioxin contamination, the European Commission and particularly the Standing Veterany Committee were going through a crisis of confidence because of the criticisms regarding the management of BSE problems. The European Commission was resigning at that moment.

It is in this precise context that the Rapid Alert System informed the European Commission on May 28 $8^{\text {th }} 1999$ (the Commission meets twice a month). Standing Veterany Committee held a meeting on May 31 th 1999 and blamed Belgium for the late notification.

On the other hand, a disagreement appears between the Belgian authorities and the Commission on the length and/or importance of the crisis. According to Belgium, the contamination was limited (between January and February according to the former Prime Minister when he answered the official parliamentary inquiry, report page 243) while according to the Commission, the contamination was unique and massive, spread over a long period of time (Document 399D0788, already referred to).

On the basis of a personal analysis, Belgium had already established a short list of companies concerned by the contamination, but the list was contradictory and constantly modified. The Commission reacted by a blocus of all products potentially contaminated (even some cosmetic brands using eggs) and imposed a list of potentially contaminated companies. Therefore, the Belgian authorities withdrew their lists (based on tracking and apparently impossible to manage) by the end of July. They adopted the systematic analysis of PCBs before the marketing of all food supplies under scrutiny. This was possible because of a specific PCBs/dioxins ratio for the current contamination. The Commission authorised PCB analysis instead of dioxin analysis for the milk, the poultry and derived supplies on July $9^{\text {th }}$; and for bovine and pork on august $6^{\text {th }}$. The crisis could resume.

The European Commission learned some lessons from this failure in the food chain protection strategy, which was added to the problems of BSE.

The Commission found three reasons for this failure (Document 500PC0162; Proposal for a European Parliament and Council Directive amending Council Directive fixing the principles governing the organisation of official inspections in the field of animal nutrition and Council Directive on undesirable substances and products in animal nutrition. Amendments. Document delivered on 27/12/2000):

- Deficiencies in managing the crisis and in particular poor co-ordination between different authorities, emerged and were also identified by a Commission inspection.

- The Commission was not able to adopt emergency safeguard measures covering feeding stuffs only because the contamination was due to a product of supposed animal origin.

- The information on the dioxin contamination was provided late to the Commission and the measures taken at national level were not sufficient.

A white book on foodstuff protection was presented to the Commission on January $12^{\text {th }}$ 2000 (COM (1999)719final).

On this basis, the Commission prepared some important modifications of its regulations (Document 500PC076; Proposal for a Regulation of the European Parliament and of the Council laying down the general principles and requirements of food law, establishing the European Food Authority, and laying down procedures in matters of food. Amendments. Document delivered on: $27 / 12 / 2000$ ).

The proposal aims at the creation of a European Food Authority (EFA) at a community level in order to issue scientific and technical independent advice with a clear distinction between risk evaluation and risk management. The Rapid Alert System could be extended to 
animal foodstuff on top of human foodstuff. The daily management of RAS will be the responsibility of EFA. EFA will also have as a mission to collect and analyse the data related to food supplies security. Its status should guarantee independence, transparency, respresentativity and the responsibility of contributors as well as their mission.

\section{Determination of the type and importance of the contamination}

The type of contamination was very long to be determined. In March, the nutritionist (NUT) issued the hypothesis of a dioxin contamination. But the hypothesis of a contamination by askarels was only mentioned on June $3^{\text {rd }} 1999$ by P. Sandra (University of Gent) who brought the information to the medias' attention. Actually some poultry and livestock farmers had asked him to analyse several samples and he found a similar profile compatible with arochlore 1254 and 1260 . This point is very important because it allowed the Belgian government to propose the European Commission a modification in the process of detection of contaminated food through the dosage of PCBs. The tracking was indeed impossible. The modification was already admitted on June $8^{\text {th }}$ and officially accepted on June $11^{\text {th }}$. On the other hand, this also allowed to better understand the mechanism of contamination and its unique origin.

There are no norms in Europe concerning PCBs in food supplies. Belgium proposed its own level of $1 \mu \mathrm{g} / \mathrm{g}$ of fat. The Commission took a different decision with a level of $200 \mathrm{ng} / \mathrm{g}$ of fat and $100 \mathrm{ng} / \mathrm{g}$ of fat for milk since June (sum of the seven PCB marker congeners: 28, 52, 101, 118, $138,153,180)$. This level was reached by the simple ratio of $\mathrm{g}$ PCB /g TEQ-dioxin found in the contamined foodstuffs. The ratio was of $50,000 / 1$ (1). On the basis of this limit of residual concentration of TEQ equivalent of $4 \mathrm{pg} / \mathrm{g}$ of fat, the limit was therefore $200,000 \mathrm{pg}$ PCBs/g of fat (the limit proposed by WHO is $500 \mathrm{ng} \mathrm{PCB} / \mathrm{g}$ of fat). These levels were issued only for Belgium because they were specific of this precise contamination. It is however possible that they become a generalised standard. On the other hand, the Commission imposed to analyse all food supplies containing more than $2 \%$ of animal fat or $2 \%$ of eggs or more than $2 \%$ of egg products containing more than $10 \%$ of egg fat.
The limit of $4 \mathrm{pg}$ TEQ/g fat is an action level based on a estimate of experts (the Standing Veterany Committee), which is close to the previous limit of 5 pg TEQ per $g$ fat established in Belgium and Netherlands for milk. It has probably been taken into account of possible fluctuation in the ratio $\mathrm{PCB} /$ dioxin, more especially as this ratio was not held at the analysis of pig fat (the explanation proposed different metabolisation of components according to their degree of chlorination (2)). It was thus considered that if the analysis was lower than $200 \mathrm{ng} \mathrm{PCB} / \mathrm{g}$ of fat, the food safety was ensured and the product could be marketed. If the analysis was between 200 and $500 \mathrm{ng} \mathrm{PCB} / \mathrm{g}$ fat, a complementary dioxin analysis was to be carried out. The food safety was assured if the concentration of dioxin was lower than $4 \mathrm{pg}$ TEQ/g of fat. If the analysis was higher than $500 \mathrm{ng}$ PCB / $\mathrm{g}$ fat, the product could not be marketed. For comparison, note that the load in TEQ of the Belgian feeding is an average of approximately $0.4 \mathrm{pg}$ TEQ by $\mathrm{g}$ of ingested fat. These special restrictions were lifted after September $20^{\text {th }}$ (Commission decision 00/150/EC).

The extent of the contamination was obviously not considered in the same way by Belgium as by the European Commission.

In September 1999, A. Bernard (1) suggested the hypothesis of a brief contamination, limited in quantity: $50 \mathrm{~kg}$ of PCBs and $1 \mathrm{~g}$ of TEQ equivalent for dioxins/furanes. This suggestion was not questioned by any of the experts answering the Belgian official parliamentary inquiry.

The analysis of A. Bernard is based on 5 samples of PCBs and dioxins ranging from 1 to $500 \mu \mathrm{g} / \mathrm{g}$ of fat. On basis of the above mentioned article, it is not possible to understand the link between the lab results and the extent of the contamination.

Using data issued by the Belgian administration, we tried to do our own estimation. Out of 6368 cumulated analyses performed until October $10^{\text {th }} 1999$ on PCB levels in nutrition fat for animals, 124 were over the official limit of $200 \mathrm{ng} / \mathrm{g}$ of fat. However, only 4 of them were over the limit of $5 \mu \mathrm{g} / \mathrm{g}$ of fat. These 4 analyses are the control tests concerning the beginning of the contamination (and represent only the sum of the seven PCB marker congeners, representing 30\% of all PCBs). These 4 analyses are among the very rare results allowing to track the origin of the contamination $(453,336,332$ and $220 \mu \mathrm{g} / \mathrm{g}$ of fat, i. e. an average of $335 \mu \mathrm{g} / \mathrm{g}$ of fat). 
According to the administration, 80 tons of frying fat are concerned by these results, mixed with 50 tons of animal fat. On this basis, we may compute a contamination of $44 \mathrm{~kg}$ of PCBs (cumulated only over the 7 PCB marker congeners). The total contamination is therefore of $150 \mathrm{~kg}$ of arochlore 1254 and 1260 . This figure implies two levels of effects quite distinct from each other. The first impact is the direct effects of PCBs (3) and we'll go back to it later. The second impact is the dioxin-like effects. A. Bernard proposes a toxic effect linked to dioxin-like components (co-PCBs, furane, dioxin) of about $3 \mathrm{~g}$ of TEQ equivalent (2). Out of a total yearly production $300 \mathrm{~g}$ of TEQ equivalent in Belgium, the added quantity is low, around $1 \%$. However, this added quantity was more specifically concentrated in the food supply.

From a Public Health point of view, we know very little about eating habits of the Belgian population. According to Luc Hens (Vrije Universiteit Brussel, page 72 of the report), questioned by the parliamentary inquiry, his computation for the dioxin-like effects is the following: if it is admitted that over $1 / 3$ of the pollution was introduced in the food supply, the range of expected cancer cases will be between 40 and 8000 . This result is based on the cancer risk data already published $(4,5)$.

On these estimations, we have realised a very rough computation based on a linear nothreshold hypothesis. This rough computation gives, for $1 / 3$ of the total contamination ( $3 \mathrm{~g}$ I-TEQ) entering into the food, a human exposition of $1 \mathrm{~g}$ I-TEQ. A lower bound slope gives a cancer risk of $0.4 \mathrm{mg}$ aroclor $1260 / \mathrm{kg} /$ day (4, animal studies) and an upper bound slope of $7.710^{-3}$ per pg TEQ/Kg/day (5, occupational cohort). Thus, the rough risk could be comprised between 20 and 7500 supplementary cancers. These findings are in accordance with the estimation of Luc Hens, and should certainly not be neglected from a public health point of view. We have also to focus on the dioxin well known effect on thyroid (6). It is too, and not the last, a real preoccupation in the follow-up of the crisis. But we cannot neglect the benefit of the crisis. A real improvement of the feeding habits of the population is observed, and a better survey of the food safety and quality is a consequence of the crisis.

Concerning the proper effects of PCBs, our analyses diverge from others. We actually think that the $150 \mathrm{~kg}$ of askarel introduced in our food will have some public health effects, in particular for newborn infants when the mother was exposed (7). From this point of view, we deplore the attitude of the Belgian authorities who did not initiate a scientific follow-up of the most fragile population exposed during the crisis.

The two Belgian governments who had to manage the dioxin crisis and to face the distressing decisions taken by the European Commission defended the idea of a little contamination limited in time (January / February): around $50 \mathrm{~kg}$ of arochlore 1254 and 1260 in a proportion of 25/ 75 (2) which was only partly introduced in the food supply chain. Since this contamination was not supposed to generate a real public health problem, any scientific health study would substantiate the Commission's opinion about a massive and long lasting contamination. From this point of view, it is interesting to highlight the former prime minister's opinion (official inquiry report, page 243): “... He estimated that it was the scientific community's duty to express its opinion, once informed of the measures taken by the European Commission. They could have relativised the problem..."

Actually, the Belgian scientists reacted in quite a fragmented manner. There are here some discrepancies with the Yusho accident (8). The contamination (around $280 \mathrm{~kg}$ of PCBs - kanechlor 400) arrived through rice oil in February 1968. The accident had serious human consequences because, unlike the Belgian case, there were no biological sentinels, which could allow an early detection of the problem. Besides, the contamination concentrated in one type of foodstuff only. However, as soon as the Yusho accident was disclosed by a local newspaper on October $10^{\text {th }} 1968$, things will evolve very fast. On October $19^{\text {th }}$, a large Study Group for Yusho was created. On October $31^{\text {th }}$, the cause of the contamination was discovered and on November $2^{\text {nd }}$, the public was informed.

\section{CONCLUSIONS}

Two elements played an important role in the detection of the contamination.

- The animals, which were first exposed to the contamination, were very fragile (poultry).

- The animal food trade company owned a GMP accreditation and therefore realised a tracking of health problems encountered in the livestock of its clients. 
Other important factors explain the politicoeconomical crisis:

- The Belgian government disclosed all information only at the time of the confirmation of the results, keeping secret the preliminary positive results.

- The governmental communication was perceived as being very fragmented since it focused on animal food supply contamination, with little information disclosed on human food contamination.

From that moment, the Belgian authorities were not credible any more. The obsessive fear of contaminated foodstuff reached its maximum level 18 days after the governmental communication, through the "coke" syndrome, leading to a "mass sociogenic illness" (9).

The attitude of the European authorities may seem quite severe with regard to the relative importance of an obviously unique contamination. This attitude is however logical according to the precautionary principle and with regard to uncertainties surrounding the type and importance of the contamination and the incomplete protection measures applied by the Belgian authorities.

On the long term, the crisis did not have negative effects. Belgium resumed its previous levels of food production alongside a very high quality control. Other European countries and the European Community modified their administrative measures after the lessons taught by the successive BSE and dioxin crises. It must also be noted that since this incident, the public authorities more often refer to a board of experts in case of significant public health problems.

In 1998, France created a central organ for food security (AFSSA : Agence Française de Securité Sanitaire des Aliments). Great Britain organised in 1999 a central administration for information, but no control (Food Standards Agency). Denmark, The Netherlands and Belgium also created central administrations for information, expertise and control. Germany is also currently working out a central agency for food safety, which will replace the competent authorities at the level of the federated landers (10). The late crisis of BSE will certainly fasten the process.

Finally, the European Community is about to unify several expertise organs into the "European Food Authority", on the basis of the white book of food security published in 2000 (COM (1999)
719 final).

From the public health point of view, we agree with Luc Hens' opinion on the long-term contamination due to dioxin-like effects. He estimates a $10 \%$ increase of dioxin-like elements in the body, unequally distributed in the population. This could lead to 40 to 8000 cancer cases. Other effects are possible, like those on the thyroid. We may also expect the specific effects of PCBs on the most fragile populations, $i$. e. pregnant and lactating women, their infants being the last element of trophic level chain of organochlorines. Finally, we can worry about the possible long term cumulated effects of the total POPs of industrial origin to which we are exposed, even though the present situation seems to be more favourable than before.

Acknowledgements.

R. Lagasse and A. Lecomte for their reviewer's work, and M. Bigdeli for her collaboration.

\section{REFERENCES}

Usefull URL:

European documents: http://europa.eu.int/eur-lex/en/index. html

Dioxin belgian gouvernement documents: http://www.dioxin. fgov.be/

Belgian parliamentary inquiry report, and annexes (in French and Dutch): http://www.lachambre.be/documents/18/7.pdf http://www.lachambre.be/documents/18/8.pdf

1. Bernard A., Hermans C., Broekaert F., De Poorter G., De Cock A., Houins G. (1999) Food contamination by PCBs and dioxin. Nature, 401, 231-232.

2. Bernard A., (2000) La contamination alimentaire par les PCBs/dioxines en Belgique: analyse d'un accident aux conséquences sanitaires improbables. Bull. Mem. Acad. R. Med. Belg., 155, 195-201.

3. Rice D.C. (1999) Behavioural impairment produced by low-level postnatal PCB exposure in Monkeys. Environ. Res. A80, S113-S121.

4. Cogliano V.J. (1998) Assessing the cancer risk from environmental PCBs. Environ. Health Perspect., 106, 317-23.

5. Becher H., Steindorf K., Flesch-Janys D.. Quantitative cancer risk assessment for dioxins using an occupational cohort. Environ. Health Perspect, 106 (suppl2), 663-70.

6. Nagayama J., Okamura K., Iida T., Hirakawa H., Matsueda T., Tsuji H., Hasegawa M., Sato K., Ma H., Yanagawa T., Igarashi H., Fukushige J, Watanabe T. (1998) Postnatal exposure to chlorinated dioxins and related chemicals on thyroid hormone status in japanese breastfed infants. Chemosphere 37, 1789-93.

7. Patandin S., Lanting C.I., Mulder P.G.H., Boersma E.R., Sauer P.J.J., Weisglas-Kuperus N. (1999) Effects of environmental exposure to polychlorinated biphenyl's and dioxins on cognitive abilities in Dutch children at 42 months of age. J. Pediatr. 134, 33-41.

8. Kuratsune M., Yoshimura H., Hori Y., Okumura M., 
Masuda Y.. Yusho. (1996) A human disaster caused by PCBs and related compounds. Kyushu University Press. Fukuoka, japan.

9. Nemery B., Fischler B., Boogaerts M., Lison D. (1999) Dioxins, coca-cola, and mass sociogenic illness in Bel- gium. Lancet, 354, 77.

10. Services des affaires européennes. (2000) Etudes des législations comparées. Le contrôle de la sécuritê alimentaire. LC 74. Sénat franÇais. 